\title{
Impact of Silica Sand Granulometry on Bending Strength of Cores Produced by ASK Inotec Process
}

\author{
Martin Conev ${ }^{1}$, Iveta Vasková ${ }^{1}$, Martina Hrubovčáková ${ }^{1}$, Peter Hajdúch ${ }^{2}$ \\ ${ }^{1}$ Institute of Metallurgy, Faculty of Metallurgy, Technical University in Košice, Slovakia, E-mail: martin.conev@tuke.sk, \\ iveta.vaskova@tuke.sk, martina.hrubovcakova@tuke.sk \\ ${ }^{2}$ Nemak Slovakia s.r.o., Žiar nad Hronom, E-mail: peter.hajduch@nemak.com
}

\begin{abstract}
Nowadays, constant pressure on enviromental aspects in the foundry industry is calling for an improvement in casting production. The almost not used inorganic binders are coming back to the fore. Into this group, among others, belong binders based on alcali silicate solutions, known as water glass. The new hot-curing binder systems were introduced by different binder manufacturers. In order to compensate dissadvantages of alkalic silicate binder, the systems and processes are working with additives and adjuvants which are contained in a binder itself or added in liquid or powder form to the sand mixture. This paper presents the ASK Inotec process and impact of silica sand granulometry on achieved core mixture strength, which is important from a core production and also from a decoring ability point of view. Experiment was performed in laboratory terms using standard equipment and conditions.
\end{abstract}

Keywords: Silica sand, Granulometry, Inorganic binder, ASK Inotec process, Bending strength

\section{References}

[1] WALLENHORST, C. (2010). Chemical Background of Inorganic Binder systems - Focus on Core Production at the Molecular Level. In: Giesserei Rundschau. Vol. 57, No. 3/4, pp. 50 - 52. VÖG, Austria

[2] PETRŽELA, L. (1947). Způsob výroby formovaných útvarů z pisku nebo z jiného práškovitého, zrnitého, kašovitého nebo tekutého materiálu. Patent Nr. 81931. Filling date 12. Dec. 1947.

[3] POLZIN, H. (2014). Inorganic binders for mould and core production in the foundry. pp. 115 - 117. Schiele \& Schön GmbH, Berlin.

[4] BOUNDLESS CHEMISTRY (2015). Condensation reactions. Retrieved on 12. Feb. 2016. May be accessed at: www.boundless.com/chemistry/textbooks/boundless-chemistry-textbook/polymers-24/synthetic-organic-polymers-173/condensation-reactions-657-5664

[5] ASK Chemicals GmbH (2015). INOTEC The Inorganic Binder System. Presentation

[6] ASK Chemicals GmbH (2016). Inotec process. Retrieved on 2. Feb. 2016. May be accessed at: www.ask-chemicals.com/foundry-products/products/inotec-binder-system/inotec-process.html

[7] MAJOR-GABRYŚ, K., DOBOSZ, S.M., JAKUBSKI, J. (2013). Modified hydrated sodium silicate as a modern binder for ecological moulding sands. In: Manufacturing Technology. Vol. 13, No. 1, pp. 68 - 73. UJEP. Czech republic

[8] RUSÍN, K., BRYCHTA, R. (2005). Co určuje cenu jádrových směsí s křemennými ostřivy? In: Mouldding materials and cost reductions for casting. $8^{\text {th }}$ International conference almanac, pp. 37 - 52. CFS, Czech republic

[9] YEKINNI, A.A., BELLO, S.K. (2013). Investigation and Comparative Analysis of Clay Content, Grain Size and Grain Size Distribution of Foundry Moulding Sands. In: International Journal for Managment Science And Technology. Vol. 1, Issue 7, paper 1. IJMST

[10]PASTIRČÁK, R., KRIVOŠ, E. (2013). Effect of opening material granularity on the mould properties and the quality of castings made by patternless process technology. In: Manufacturing Technology. Vol. 13, No. 1, pp. 92 - 97. UJEP. Czech republic

[11]IS 1918 (1966). Methods of physical tests for foundry sands. Indian standards. Bureau of Indian standards, India

[12]JELÍNEK, P. (1970). Teorie slévárenské formy část I. Slévárenské formovací směsi. pp. 14 - 21. VŠB, Czech republic 